\title{
Policy incentives for flexible district heating in the Baltic countries
}

\author{
Sneum, Daniel Møller; Sandberg, Eli; Koduvere, Hardi; Olsen, Ole Jess; Blumberga, Dagnija
}

Published in:

Utilities Policy

Link to article, DOI:

10.1016/j.jup.2018.02.001

Publication date:

2018

Document Version

Peer reviewed version

Link back to DTU Orbit

Citation (APA):

Sneum, D. M., Sandberg, E., Koduvere, H., Olsen, O. J., \& Blumberga, D. (2018). Policy incentives for flexible district heating in the Baltic countries. Utilities Policy, 51, 61-72. https://doi.org/10.1016/j.jup.2018.02.001

\section{General rights}

Copyright and moral rights for the publications made accessible in the public portal are retained by the authors and/or other copyright owners and it is a condition of accessing publications that users recognise and abide by the legal requirements associated with these rights.

- Users may download and print one copy of any publication from the public portal for the purpose of private study or research.

- You may not further distribute the material or use it for any profit-making activity or commercial gain

- You may freely distribute the URL identifying the publication in the public portal

If you believe that this document breaches copyright please contact us providing details, and we will remove access to the work immediately and investigate your claim 


\title{
Policy incentives for flexible district heating in the Baltic countries
}

\author{
Daniel Møller Sneum ${ }^{\mathrm{a}, *}$, Eli Sandberg ${ }^{\mathrm{b}}$, Hardi Koduvere ${ }^{\mathrm{c}}$, Ole Jess Olsen ${ }^{\mathrm{d}}$, Dagnija Blumberga ${ }^{\mathrm{e}}$ \\ a DTU Management Engineering, Systems Analysis Division, Produktionstorvet, Building 426, DK-2800 Lyngby, Denmark \\ ${ }^{\mathrm{b}}$ Faculty of Environmental Sciences and Natural Resource Management, Norwegian University of Life Sciences, PO Box 5003, N-1432 Ås, Norway \\ ${ }^{\mathrm{c}}$ Tallinn University of Technology, School of Engineering, Department of Electrical Power Engineering and Mechatronics, Estonia \\ d DTU Management Engineering, System Analysis Division, Denmark \\ ${ }^{\mathrm{e}}$ Riga Technical University, Institute of Energy Systems and Environment, Faculty of Power and Electrical Engineering, Latvia
}

\section{A R T I C L E I N F O}

\section{Keywords:}

District heating

Flexibility

Energy policy

\begin{abstract}
A B S T R A C T
This study analyzes the impacts of taxes, subsidies, and electricity transmission and distribution tariffs and heat storage on the operation and economic feasibility of district heating plants with different flexibility potentials in the Baltic countries. Under 2016 conditions, the lowest levelized cost of heat is achieved by a combination of wood chip boilers, electric boilers, and heat storage. Heat storage enables a higher utilization of least-cost technologies, resulting in greater cost efficiency for all considered scenarios. Current taxes and subsidies are found to have limited impact on the operation of combined heat and power plants and electric boilers.
\end{abstract}

\section{Introduction}

The renewable shares of 2014 total final energy consumption in Estonia, Latvia, and Lithuania were 25, 40 and 28\%, respectively. These shares have increased steadily since the dissolution of the Soviet Union in 1991, when they were 3, 18, and 3\% (The World Bank, 2017). The renewable share in Baltic district heating $\left(\mathrm{DH}^{1}\right)$ systems is already significant: In 2015, biofuels represented 43, 37, and 59\% of DH in Estonia, Latvia, and Lithuania, respectively, most of which was solid biomass (IEA, 2017). Heat-only boilers and combined heat and power (CHP) options, which use biomass as their only fuel source, are, therefore, currently common in the Baltic countries. In addition to biomass, the main fuels used in DH are natural gas and waste (Sneum et al., 2016). In 2015, the three Baltic countries managed a combined net export of more than four million tons of fuelwood (Eurostat, 2017), indicating strong potential for regional biomass development. The renewable share in the Baltic energy systems is expected to increase further, as energy and climate policy indicate a general future increase in renewable energy across the $\mathrm{EU}$ member states to achieve compliance with national action plans for the 20-20-20 targets (e.g., the Latvian Guidelines of Energy Development for 2016-2020 (Likumi, 2016)), and the proposed EU 2030 targets (European Commission, 2014). Assuming that a proportion of this increased share of renewable energy will stem from variable renewable energy (VRE) sources, such as wind power and solar photovoltaics, there may arise an increased need for a well-integrated and flexible energy system. The matter of security of supply and energy imports adds to this picture. The Baltic countries are largely dependent on imported fossil fuels (Roos et al., 2012). The Ignalina nuclear power plant in Lithuania accounted for $70 \%$ of the country's electricity production before it was shut down in 2009 (IEA, 2014a), and Lithuania's dependence on imported energy resources has increased remarkably since the closure, growing from 50 to $62 \%$ to approximately $80-82 \%$, exceeding the EU average of $53-54 \%$ (Gaigalis et al., 2016). To decrease its dependency on imports, Lithuania has been prioritizing an increase in the renewable energy share (Lund et al., 2005).

Due to the increase in renewables and the possible following need for an integrated, flexible energy system, this study asks the following research question:

How do policies, in the form of taxes and subsidies, incentivize investment in technologies which flexibly couple the $\mathrm{DH}$ and the electricity systems in the Baltic countries?

DH facilitates the interaction between electricity and heat production. In the Baltic context, this has been illustrated by Kuhi-Thalfeldt and Valtin (2009), who describe how VRE can be balanced by local small-scale CHP plants in Estonia. In Latvia, Bazbauers and Cimdina (2011) shows that it is possible to increase the share of renewable

\footnotetext{
* Corresponding author.

E-mail addresses: dasn@dtu.dk (D. Møller Sneum), elisand@nmbu.no (E. Sandberg), hardi.koduvere@ttu.ee (H. Koduvere), oleo@dtu.dk (O.J. Olsen), Dagnija.blumberga@rtu.lv (D. Blumberga).

${ }^{1}$ Abbreviations: CHP: combined heat and power, DH: district heating, DSO: distribution system operator, EB: electric boiler, EE: Estonia, LCOH: levelized cost of heat, similar to the

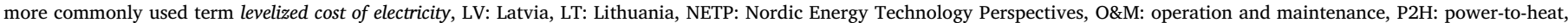
PSO: public service obligations, T\&D: transmission and distribution, TSO: transmission system operator, VRE: variable renewable energy.
} 
energy sources by combining the surplus electricity produced by wind power in heat pumps with heat storage. Mathiesen et al. (2015) termed such flexible coupling in the energy system smart energy systems. Other studies demonstrate that $\mathrm{CHP}$ and power-to-heat (P2H) technologies, such as electric boilers (EB), may support flexibility in smart energy systems (Blarke, 2012; IEA, 2014b; Lund, 2003; Lund et al., 2015). An important enabler of such system integration is heat storage, which allows a partial decoupling of heat production and heat demand; e.g., by allowing a CHP to generate electricity whenever the electricity price is high and store the excess produced heat (Colmenar-Santos et al., 2016). This coupling of heat generation and electricity is already practiced in CHPs in the Baltic countries. Storage capacity and $\mathrm{P} 2 \mathrm{H}$ technologies, however, are currently virtually nonexistent in Baltic DH (Sneum et al., 2016).

DH constitutes more than $50 \%$ of households' energy demand for heating, and the CHP share is above $50 \%$ of the $\mathrm{DH}$ production in Latvia and Lithuania, as seen in Figs. 1 and 2. The potential to deploy DH as a flexibility provider in the Baltics is, thus, considerable.

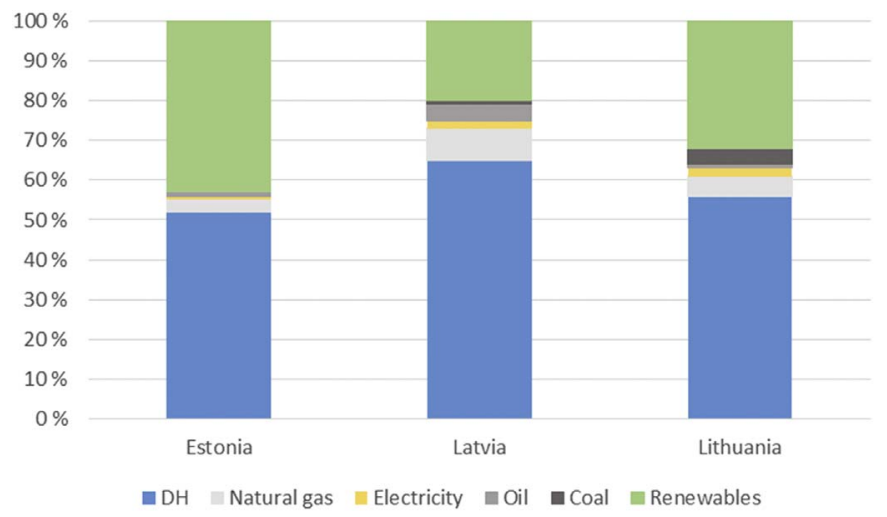

Fig. 1. Share of residential energy consumption for heating in the Baltic countries in 2013 (Euroheat and Power, 2015).
The present energy policies of the Baltic countries in terms of taxes and subsidies are not favorable for exploiting this potential. Feed-inpremiums promote CHP for the sake of security of supply and the use of domestic fuels. The electricity used for $\mathrm{DH}$ production is subject to the same tax rates as any other electricity consumption, reducing incentives for $\mathrm{P} 2 \mathrm{H}$ deployment. The decision to invest in heat storage is entirely determined by market incentives (Sneum et al., 2016).

The objective of this paper is to investigate the feasibility of flexible DH technologies in a future electricity system comprised of a large share of VRE in the three Baltic countries, which assumes a greater need for flexibility options. We accomplish this by modelling different compositions of a DH system under current policies in terms of taxes and subsidies to find the resulting heat production costs. Furthermore, the impacts of electricity T\&D tariffs and heat storage are explored. This approach shows if combinations of DH technologies and current policies produce both low heat costs and an opportunity for coupling DH with the electricity system.

Section 2 describes the methodology of the study, and Section 3 presents the results of the analyses. Section 4 concludes the study.

\section{Methodology}

This study analyzes the impacts of taxes and subsidies on investment incentives. Using the analysis tool energyPRO (EMD International A/S, 2018), we developed a model for DH plants with different degrees of coupling to the electricity system and, thus, different potentials for providing flexibility. The inputs and policies for the model plants are derived from the policy schemes for the different Baltic countries. By applying current economic conditions to the model plants, we test whether it is economically feasible to invest in flexible technologies in the Baltic countries. Earlier studies have addressed and modelled alternative policies for the operation of (Skytte et al., 2017) and investment in DH plants by taxation (Olsen and Munksgaard, 1998), using the capacity factor as a measure (Athawale and Felder, 2014). This study extends these methods by including storage, hourly variations, and long-term changes in fuel and electricity prices. The focus is on heat production costs, measured as the levelized cost of heat (LCOH).

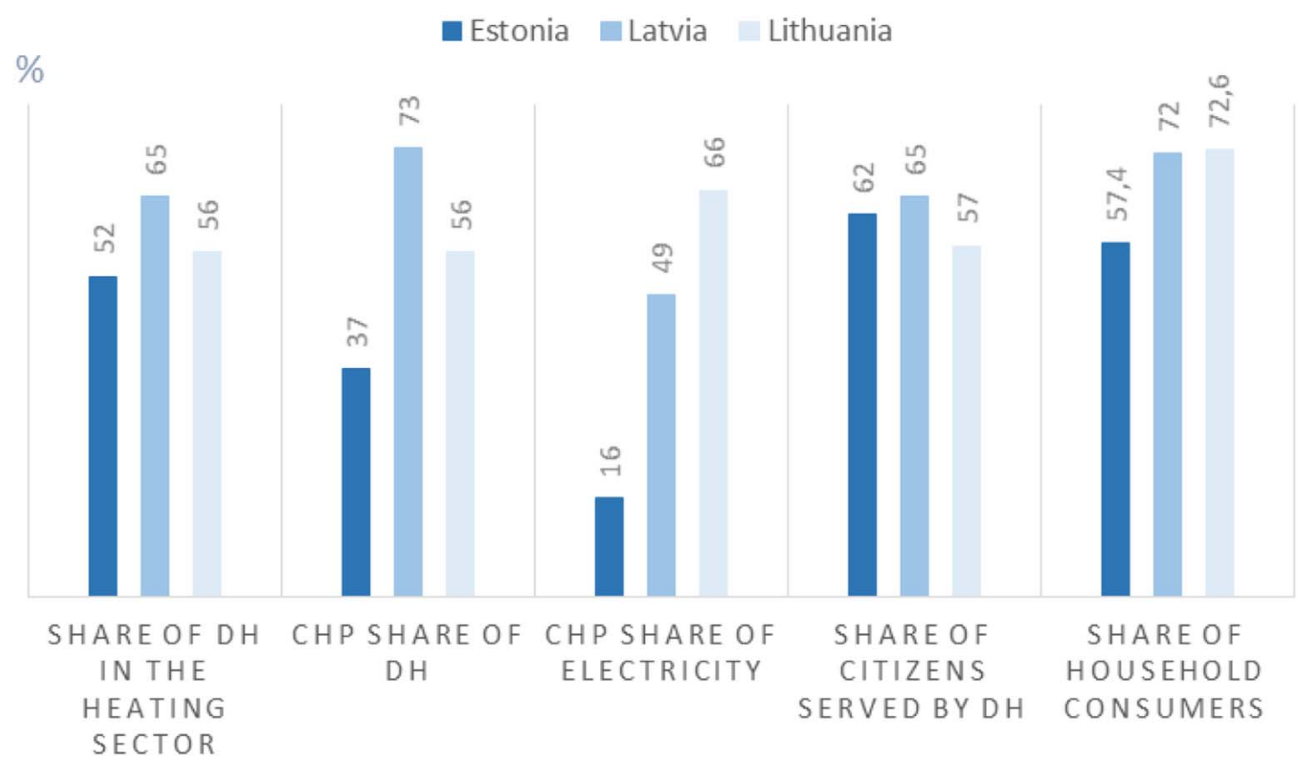

Fig. 2. Key figures in Baltic district heating shares in 2013 (Euroheat and Power, 2015). 


\subsection{Definition of flexibility}

The operation of DH technologies facilitated by policies is an important part of this study, whereas an analysis of flexible operation falls outside the study's scope. Nonetheless, flexibility is a key element of the study, since it is a characteristic assigned to some of the analyzed technologies.

This study defines flexibility as the ability of a DH technology to frequently and quickly increase or decrease its consumption or production of electricity in response to system signals and needs. Conversely, an inflexible DH technology is one that does not possess these attributes. This definition is in line with the more electricity-oriented definition applied by Lannoye et al. (2015), the grid interfaceoriented definition proposed by Salpakari et al. (2016), and the energy system-oriented definitions applied by Lund et al. (2005) and Mathiesen et al. (2015). One proxy for flexibility need is the forecast price of electricity on the spot market. Low spot prices indicate an oversupply, which can be mitigated by a decrease in electricity production or an increase in electricity consumption (and vice versa for high electricity prices).

The ability of DH to respond to the needs of the electricity system depends on the technology of the installed plant and on the incentives for operating it. Investment incentives for flexibility should favor technologies capable of interacting with the electricity system, and operational incentives should not blur the signals created by the electricity spot market. This study addresses both the investment and operational incentives affecting the economic feasibility of flexible technologies.

\subsection{What does the literature say about Baltic DH and flexibility?}

A review of the literature on policy alternatives for Baltic DH reveals that extant research has focused primarily on increasing the share of renewables. From the Soviet era, Baltic DH inherited old, over-capacitated, and inefficient DH plants dependent on imported fuels (Lauka et al., 2015; Lund et al., 1999; Roos et al., 2012). Researchers have discussed ways for the Baltic energy sector to adapt to a market economy. CHP is frequently mentioned, as it is considered a means to utilize domestic fuels (Lund et al., 2005) and increase energy efficiency (Ziemele et al., 2016) and the renewable share in Baltic DH (Konstantinaviciute et al., 2013; Perednis et al., 2012). EBs are not mentioned. A few studies mention heat pumps in combination with heat storage (Bazbauers and Cimdina, 2011; Colmenar-Santos et al., 2016; Lauka et al., 2015). With respect to the Baltic energy sectors, the focus is on energy efficiency and increasing the share of domestic fuels in order to decrease DH prices (Kveselis et al., 2017; Ziemele et al., 2016) and reduce import dependency (Lund et al., 1999; Miskinis et al., 2006). The choice of renewable fuels for domestic fuels stems from environmental concerns. Within this body of work, flexibility is rarely mentioned, though it could be considered in the planning of long-term energy investments, concerns related to climate gas emissions and the adoption of fourth-generation DH (Ziemele et al., 2016). Flexibility is given greater attention in more recent work (Bergaentzle et al., 2017; Kuhi-Thalfeldt and Valtin, 2009).

\subsection{Operation and investment analysis}

The adoption of DH technologies may be affected by taxation and subsidization. Energy taxes within DH can be used to address negative externalities associated with production as well as for fiscal purposes (Olsen and Munksgaard, 1998). Subsidies can be used to address policy priorities, such as promoting the use of certain fuels.
In the Baltic countries, transmission and distribution system operators charge for services provided by the grid infrastructure according to electricity tariffs. Like taxes, tariff structures differ in design and levels. Larger or smaller cost-shares of electricity consumption can be allocated to fixed and variable (marginal) costs, respectively (Soysal et al., 2016), and tariffs can be levied on the utilization of either capacity (EUR/MW) or energy (EUR/MWh).

Heat storage has been shown to have a significant impact on the operation and feasibility of DH plants, both in academic research (Streckiene et al., 2009) and in practice in Denmark (EMD International A/S, 2017). Through heat storage, operations can be optimized to utilize least-cost technologies, such as $\mathrm{P} 2 \mathrm{H}$ during periods with low electricity prices and CHP during periods with high electricity prices. Research by Sneum et al. (2016) indicated a limited use of heat storage in the Baltic countries. The present study examines this technology to determine its potential impact.

Public policies can impact investment in and operation of flexible technologies and thus their economic feasibility. This study analyzes all existing (2016) taxes, subsidies, and electricity T\&D tariffs in the Baltic region in order to determine their collective impact on plant operation and, subsequently, to measure their effect on the economic feasibility for the given DH technologies.

\subsubsection{Operation analyses in the energyPRO simulation software}

EnergyPRO is an industry operation optimization software used for techno-economic studies of DH plants (Connolly et al., 2010). The software has been used in earlier research on CHP plants with heat storage (Streckiene et al., 2009; Trømborg et al., 2017) and P2H in DH (Østergaard and Andersen, 2015). Energy demands, costs, temperatures, technologies, and other factors are incorporated as input data, and operational optimization is performed on an hourly basis, considering such constraints as storage content. Heat demand can be covered by different technologies, depending on marginal production costs defined by inputs such as fuel costs, taxes, and so on. Fig. 3 illustrates the marginal heat production cost as a dependent of the electricity cost: For $\mathrm{P} 2 \mathrm{H}$, low electricity prices mean low heat production costs (and vice versa for CHP). Exceptions are the marginal costs of fuel-based heat-only boilers (e.g., wood chip boilers), which are unaffected by electricity costs. Each technology serves as the preferred unit for dispatch depending on the price of electricity and subject to heat demand and the availability of heat storage capacity. Finally, the P2H technology case illustrates the implementation of levies, with the dotted line indicating an increase in marginal cost associated with, for example, the introduction of an electricity tax.

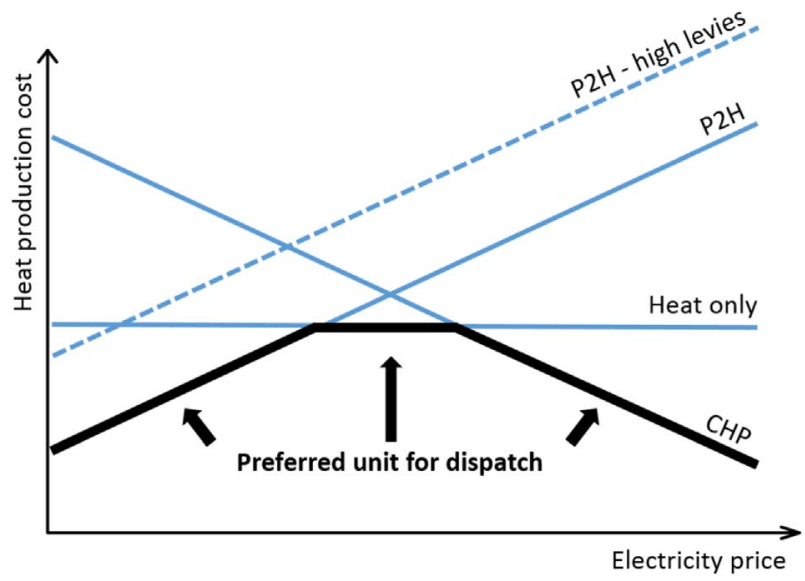

Fig. 3. Marginal heat production cost and preferred unit for dispatch in a district heating plant with a heat-only boiler, $\mathrm{P} 2 \mathrm{H}$, and CHP. 
The energyPRO software optimizes operation under perfect foresight, minimizing heat production costs based on day-ahead electricity spot prices. Perfect foresight describes that the model includes future energy prices and heat demand in its optimization. In the real-world, operators would have a similar foresight due to weather- and price forecasts, but with some added uncertainty. This is how DH plants are commonly operated in the Nordic and Baltic countries. In this study, operational optimization is conducted hourly across a 20 -year timescale (2016-2035). The perfect foresight utilized in the optimization could potentially lead to too-perfect operation. To address this issue, the $\mathrm{P} 2 \mathrm{H}$ and CHP units are only allowed to operate in a full-load manner (i.e., no partial load), which is a typical bidding strategy for the decentralized back-pressure DH plant operating on the electricity spot market.

Dispatch optimization in energyPRO is conducted by assigning priorities to the heat-producing technologies each hour based on the variables that affect the marginal heat production cost (e.g., electricity prices). The units with the highest priority (i.e., least marginal heat production cost) are committed first, and the dispatch calculation is subsequently repeated for the remaining technologies until the heat demand is fully served (EMD International A/S, 2016). Operational optimization in energyPRO has been described in further detail by Lund and Andersen (2005).

Like other types of energy storage, heat storage enables an optimized use of resources. In this study, as is the case for similar-size plants in Denmark, Finland, and Sweden, heat storage is water-based and dimensioned according to one to three days of heat demand, corresponding to $2000 \mathrm{~m}^{3}$.

\subsubsection{Feasibility study of investment incentives}

A fundamental prerequisite for the flexible operation of DH technologies is that flexible technologies are present. This, in turn, requires investment in such technologies. As noted by Olsen and Munksgaard (1998), in the case of DH, a profit-maximizing investor will select the production technology having the lowest long run production costs taking into consideration the present tax regime including subsidies. In this study, this long-run production cost, and its subsequent role as an indicator for investment incentives, is termed $\mathrm{LCOH}$. LCOH is similar to the more commonly applied levelized cost of energy and represents the economic lifetime cost of heat generated. The LCOH calculation follows the standard approach of calculating the levelized cost of energy, as seen below.

$L C O H=\frac{\sum_{t=0}^{n} \frac{T C_{t}}{(1+r)^{t}}}{\sum_{t=0}^{n} \frac{q_{t}}{(1+r)^{t}}}$

Where.

- $\mathrm{LCOH}$ is the levelized cost of heat

- $n$ is the number of years
- $t$ is the given period

- $r$ is the discount rate

- $T C_{t}$ is the total cost in period $t$

- $q_{t}$ is the heat production in period $t$

$T C_{t}$ is further specified below, since the variable costs are a significant part of this study.

$T C_{t}=I_{t}+F O M_{t}+V O M_{t}+F_{t}+E_{t}+T_{t}+T F_{t}+T V_{t}-E_{t}-S_{t}$

Where.

- $I_{t}$ is the investment cost in period $t$

- $F O M_{t}$ is the fixed operation and maintenance cost in period $t$

- $V O M_{t}$ is the variable operation and maintenance cost in period $t$

- $F_{t}$ is the fuel cost in period $t$

- $E_{t}$ is the spot electricity cost in period $t$

- $T_{t}$ is the tax $\left(\mathrm{CO}_{2}\right.$, energy, and public service obligations) in period $t$

- $T F_{t}$ is the fixed charge under the electricity tariff in period $t$

- $T V_{t}$ is the variable charge under the electricity tariff in period $t$

- $E_{t}$ is the revenue from electricity sales in period $t$

- $S_{t}$ is the subsidy in period $t$

Revenue from heat production is not part of the equation, while electricity spot market sales are, because the purpose of calculating the $\mathrm{LCOH}$ is to determine the level at which heat must be priced for the project to be feasible at the break-even point.

While a plant's owner, developer, and operator might, in practice, be different companies, we treat them as a single aggregate entity. Athawale and Felder (2014) take a similar approach in their study of CHP plants.

\subsection{Technologies, policies, and their variations}

Table 1 details four different analyzed technological combinations for DH plants. These represent $\mathrm{DH}$ technologies with characteristics that range from flexible production and consumption (CHP and EB) to no flexibility at all (wood chip boiler). For each combination, an oil boiler is present for back-up and peak load. While DH can be produced by a multitude of technologies, we chose those that represent potential future setups in which CHP capacity is fossil-free and P2H is capable of utilizing the increased amounts of VRE in the energy system. This approach is in line with the general Baltic policy of increasing the share of domestic fuels and the efficiency of DH plants (Ziemele et al., 2016), the Latvian policy of increasing energy efficiency by increasing the CHP share and the share of renewable energy (ABB, 2012; Klavs and Kudrenickis, 2016), and the Lithuanian policy of enhancing energy efficiency and increase the renewable share, particularly by replacing natural gas with biomass in DH (Macevičius, 2015; Sekmokas, 2012).

Table 1

Technological combinations considered. The model plant load compositions are based on Norsk Energi and Thema Consulting Group (2014).

\begin{tabular}{|c|c|c|c|c|c|}
\hline \multirow[t]{2}{*}{ Technological combination } & Base load & Mid-load & Peak load & \multirow{2}{*}{$\begin{array}{l}\text { Potential flexibility: } \\
\text { Production }\end{array}$} & \multirow{2}{*}{$\begin{array}{l}\text { Potential flexibility: } \\
\text { Consumption }\end{array}$} \\
\hline & $\begin{array}{l}5.4 \mathrm{MW}_{\mathrm{TH}} \\
45 \% \text { of peak load, low } \\
\text { fuel price }\end{array}$ & $\begin{array}{l}6.6 \mathrm{MW}_{\mathrm{TH}} \\
55 \% \text { of peak } \\
\text { load }\end{array}$ & $\begin{array}{l}12 \mathrm{MW}_{\mathrm{TH}} \\
100 \% \text { of peak load, low } \\
\text { investment cost }\end{array}$ & & \\
\hline A & Wood chip CHP & $\begin{array}{l}\text { Wood chip } \\
\text { boiler }\end{array}$ & Oil boiler & $\mathrm{X}$ & \\
\hline B & Wood chip CHP & EB & Oil boiler & $\mathrm{X}$ & $\mathrm{X}$ \\
\hline $\mathrm{C}$ & $\begin{array}{l}\text { Wood chip boiler (12 } \\
\left.\text { MW }_{\mathrm{TH}}\right)\end{array}$ & - & Oil boiler & & \\
\hline $\mathrm{D}$ & Wood chip boiler & EB & Oil boiler & & $\mathrm{X}$ \\
\hline
\end{tabular}


Table 2

Policy conditions considered. *Condition 4 is included for discussion purposes only, due to the limited impact found for electricity capacity tariffs. It is addressed in Section 3.5 .

\begin{tabular}{|c|c|c|}
\hline Policy condition \# & Policy condition & Purpose \\
\hline 1 & With taxes and subsidies, no heat storage & Together with 2 , determines the impact of having storage. \\
\hline 2 & With taxes and subsidies, with heat storage & $\begin{array}{l}\text { Together with } 1 \text {, determines the impact of having storage. Together with } 3 \text {, determines the } \\
\text { impact of taxes and subsidies. }\end{array}$ \\
\hline 3 & No taxes and subsidies, with heat storage & Together with 2 , determines the impact of taxes and subsidies. \\
\hline 4 & $\begin{array}{l}\text { With taxes and subsidies, with heat storage, no electricity } \\
\text { capacity tariffs* }\end{array}$ & $\begin{array}{l}\text { Compared against } 2 \text {, determines whether investment incentives are impacted by capacity } \\
\text { tariffs. }\end{array}$ \\
\hline
\end{tabular}

All four technological combinations are subject to four policy conditions that affect DH investment incentives, as explained in Table 2. Our approach to policy follows the work of Hvelplund and Lund (1998), who describe how regulations can make economically rational, profitmaximizing actors in the energy system act in accordance with societal goals. For this study, societal goals are assumed to be some version of flexible, low-carbon DH supply. Policy conditions 1 and 2 enable an analysis of the impact of heat storage. To explore whether the policies force the DH plant to act in accordance with societal priorities, we include Policy condition 3, which enables analyses of how taxation impacts operation. The load demand tariff/capacity tariff is a charge on the maximum load demand for $1 \mathrm{~h}$ over the course of a year. Depending on their design, such grid tariffs can be either barriers to or drivers for $\mathrm{P} 2 \mathrm{H}$. Thus, we include Policy condition 4 to determine the degree of impact of capacity tariffs on $\mathrm{LCOH}$.

In summary, the technological combinations have been ordered using letters A through $\mathrm{D}$, the policy conditions have been ordered using numbers 1 through 4 , and the scenarios have been named using a combination of the letters and numbers. This scheme produces a total of 16 scenarios for each country and 48 in total, as summarized in Table 3.

Table 3

Overview of technological combinations and policy conditions applied in the analyzed scenarios. *Variations in the electricity capacity tariffs is reviewed in the discussion section.

\begin{tabular}{cllll}
\hline Technology & Storage & $\begin{array}{l}\text { Taxes and } \\
\text { subsidies }\end{array}$ & $\begin{array}{l}\text { Electricity } \\
\text { capacity tariffs }\end{array}$ & Scenario \\
\hline \multirow{2}{*}{ Wood chip CHP + EB } & - & Yes & Yes & A1 \\
& Yes & Yes & Yes & A2 \\
& & - & Yes & A3 \\
Wood chip CHP + wood & - & Yes & $*$ & A4 \\
chip boiler & Yes & Yes & Yes & B1 \\
& & - & Yes & B2 \\
Wood chip boiler + EB & - & Yes & $*$ & B3 \\
& Yes & Yes & Yes & B4 \\
& & - & Yes & C2 \\
Wood chip boiler & & Yes & $*$ & C3 \\
& - & Yes & Yes & C4 \\
& Yes & Yes & Yes & D1 \\
& & - & Yes & D3 \\
& & Yes & $*$ & D4 \\
\hline
\end{tabular}

\subsection{Data and assumptions}

To ensure that the results reflect differences in policy, not in fuel prices, we assumed the prices of oil and wood chips to be uniform for all countries. The wood chip price is an average of 2015 and 2016 prices, and the oil price is an average of 2016 prices. For each country, we used hourly Nord Pool Spot prices for electricity, since Nord Pool serves the Baltic countries and the Northern European countries due to physical trade, based on interconnections. Table 4 presents the 2016 fuel prices. Fuel and electricity prices were adjusted according to annual averages in the Nordic Energy Technology Perspectives (NETP) 2016 (IEA, 2016). This approach reflects that electricity is traded based on hourly values, while fuel is purchased in bulk via long-term contracts. The NETP 2016 analyzes transition to a carbon-neutral energy system by 2050 and, thus, provide a macro-economic framework that is thematically aligned with our study's micro-economic perspective of local transitions to renewable energy. System-scale impacts on, for example, the electricity and fuel prices of transitions to certain DH fuels or technologies are assumed to be factored in through the values drawn from the NETP 2016.

Table 4

Fuel prices applied in the modelling. Based on the European Commission (2017) and Baltpool (2017).

\begin{tabular}{ll}
\hline Fuel & 2016 PRICE - EUR/MWh \\
\hline Oil & 28.1 \\
Wood chips & 11.5 \\
\hline
\end{tabular}

Hourly values (heat demand, electricity spot prices) and annual values (fuel prices) are adjusted annually according to indices drawn from the NETP 2016. This accommodates expected development over time of e.g. reduction in heat demand due to gradually increased energy efficiency.

Table 5 displays the taxes, subsidies, and electricity T\&D tariffs applied in the present study. Electricity grid tariffs normally reflect a fixed customer charge, a capacity (or power) charge, and an energy charge; the annual or monthly capacity charge is based on the maximum electric capacity drawn from the grid and the energy charge is based on the amount of MWh consumed. 
Table 5

2016 levels of taxes, subsidies, and electricity T\&D tariffs in each of the Baltic countries. All numbers in EUR/MWh unless otherwise stated.

\begin{tabular}{|c|c|c|c|c|c|c|c|c|c|}
\hline Country & Electricity tax & PSO tariff & CO2 tax & $\begin{array}{l}\text { Energy tax } \\
\text { - oil }\end{array}$ & $\begin{array}{l}\text { Subsidy on bio } \\
\text { CHP elec. prod. }\end{array}$ & $\begin{array}{l}\text { DSO energy charge } \\
\text { [Time and seasonal } \\
\text { variation] }\end{array}$ & $\begin{array}{l}\text { DSO capacity charge } \\
\text { [EUR/MW/month based } \\
\text { on yearly max.] }\end{array}$ & TSO energy charge & $\begin{array}{l}\text { TSO capacity } \\
\text { charge [EUR/MW } \\
\text { /month based on } \\
\text { yearly max.] }\end{array}$ \\
\hline $\mathrm{EE}$ & - & 9.6 & 0.57 & 5.22 & 53.70 & $2.9-5.1$ & 3600 & $\begin{array}{l}\text { Time and seasonal } \\
\text { variation } 8.2-16.4\end{array}$ & - \\
\hline LV & - & 26.79 & 1.00 & 6.08 & - & $17.7-31.2$ & 1630 & 4.2 & 792.8 \\
\hline LT & 0.52 & 16.42 & - & 1.36 & 70.00 & $15-24$ & 580 & 1.1 & - \\
\hline
\end{tabular}

Current CHP subsidies in Estonia were introduced in 2007 to incentivize increased CHP efficiency, to displace boiler-based DH production, and to increase the use of renewable fuels in CHP (Euroheat and Power, 2015). Estonia's 12-year subsidy is provided as a feed-in premium that supplements the electricity spot price (Riigi Teataja, 2014). For Lithuania, the subsidy is a 12-year feed-in tariff (National Commission for Energy Control and Prices, 2016). Here, additional aspects of energy security play an important role in incentivizing the use of biomass in the heat sector (Kveselis et al., 2017). While Latvia also subsidizes CHP plants, this support is directed toward existing plants (Likumi, 2017) and, thus, is not included in this study.

Table 6 displays capital costs, which are divided into labor and hardware costs. This division is necessary to adjust for the differences in labor costs from the reference used (Norwegian Water Resources and Energy Directorate (2015)). Thus, hardware costs are assumed to be fixed, while labor costs are adjusted according to Baltic GDP levels using World Bank data (The World Bank, 2017). Later capital investments and all operation and maintenance (O\&M) costs are subject to inflation. The annual inflation rate (1.5-2.3\%) is based on the Danish Energy Agency (2016a). The capital cost does not include any financing. A 4\% nominal discount rate is applied to the combined capital and O\&M costs for the economic life of the plant.

Table 6

Capital costs divided into labor and hardware costs. The CHP capital cost is based on electricity output capacity, while the capital costs for the remaining technologies are based on heat output capacity.

\begin{tabular}{llll}
\hline Technology & Labor costs & Hardware costs & Total capital costs \\
\cline { 2 - 4 } & EUR per MW & EUR per MW & EUR per MW \\
\hline Wood chip boiler & 866 & 602151 & 603017 \\
Oil boiler & 2143 & 55645 & 57788 \\
EB & 2273 & 62903 & 65176 \\
Wood chip CHP & 352907 & 3239785 & 3592692 \\
Heat storage $^{\text {a }}$ & EUR for a 2000 $\mathrm{m}^{3}$ heat storage & \\
\hline
\end{tabular}

${ }^{\text {a }}$ Capital cost is allocated on labor, since split between labor and hardware cost is unknown. Cost data are from The Norwegian Water Resources and Energy Directorate (2015) and the Danish Energy Agency (2016b). Danish and Norwegian labor costs have been adjusted to Baltic labor costs.

Table 7 presents the technological assumptions. Reinvestment is necessary for the wood chip boiler, since its technical lifetime is lower than the plant's 20-year economic lifetime in our analysis. The remaining lifetimes of the technologies are included in the analysis as linear scrap values.
Table 7

Efficiencies and minimum loads for DH technologies (Danish Energy Agency, 2015; Norsk Energi and Thema Consulting Group, 2014). Lifetimes from The Norwegian Water Resources and Energy Directorate (2015).

\begin{tabular}{lllll}
\hline Technology & $\begin{array}{l}\text { Heat } \\
\text { efficiency }\end{array}$ & $\begin{array}{l}\text { Electric } \\
\text { efficiency }\end{array}$ & Minimum load & $\begin{array}{l}\text { Technical } \\
\text { lifetime (years) }\end{array}$ \\
\hline $\begin{array}{c}\text { Wood chip } \\
\text { CHP }\end{array}$ & $77 \%$ & $28 \%$ & $100 \%$ & 25 \\
EB & $98 \%$ & - & $100 \%$ & 20 \\
Wood chip & $89 \%$ & - & $25 \%$ & 15 \\
$\begin{array}{c}\text { boiler } \\
\text { Oil boiler }\end{array}$ & $92 \%$ & - & $0 \%$ & 20 \\
\hline
\end{tabular}

\section{Results}

This section presents the results for each technological combination and its scenarios based on the policy conditions affecting incentives for investment in DH technologies. The LCOH for each scenario indicates the investment incentive, detailed by the individual cost components. Insight into the operational incentives underlying the given framework conditions is drawn from the distribution of heat production. Slight deviations from the $40 \mathrm{GWh}$ heat demand occur when the model adjusts in response to local temperatures. The contents in each section refer to that section's respective figure(s).

\subsection{Combination A: wood chip CHP and wood chip boiler}

In all scenarios, heat storage enables a significantly better utilization of the biomass CHP capacity and, thereby, a lower LCOH than scenarios without storage. While cost parameters are similar, income varies. CHP production deviates only slightly among the countries, and the differences are attributable to the Estonian and Lithuanian subsidies on electricity production. In all cases, taxes and subsidies have almost no operational impact. Furthermore, in all scenarios, the wood chip CHP and EB can only operate at full capacity, meaning that periods with a lower heat demand than heat output must be supplied either by the fuel-based boilers or through a simultaneous loading or unloading of the heat storage (if present). This explains the differences in production for scenarios with and without heat storage. The same effect applies to combinations A through D (see Figs. 4 and 5). 


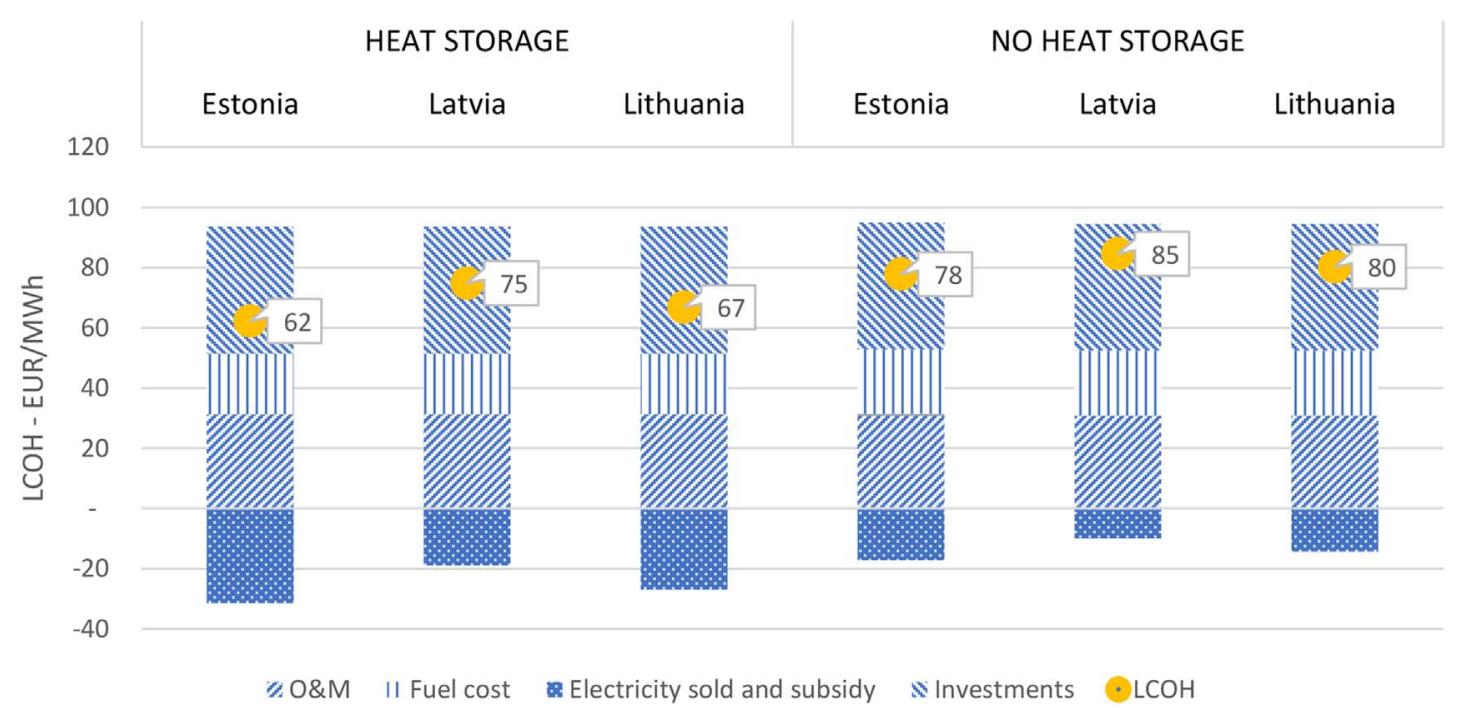

Fig. 4. Levelized cost of heat for Combination A (CHP + wood chip boiler) divided into main cost components.

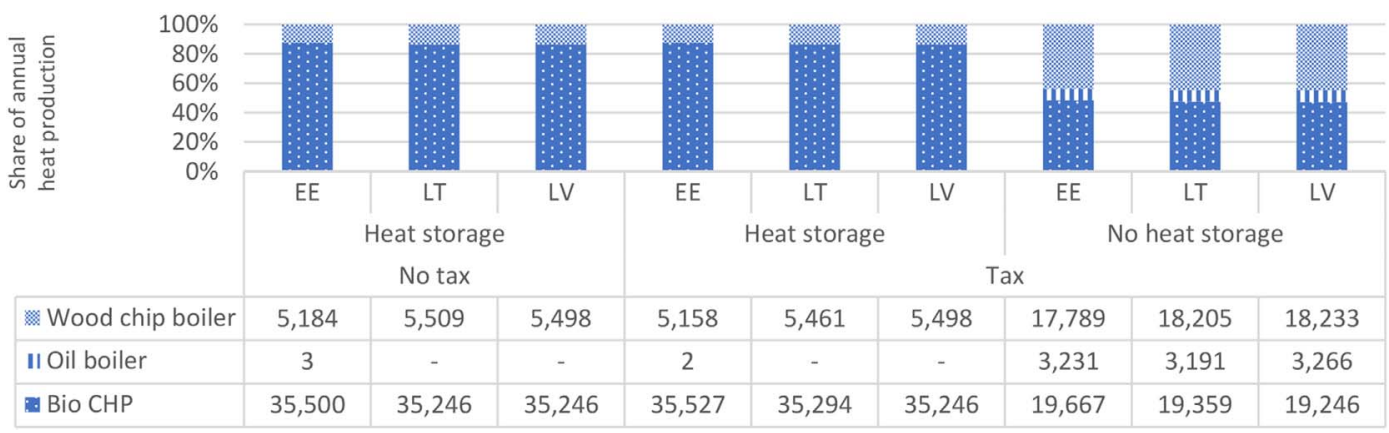

Fig. 5. Fuel distribution for Combination A (CHP + wood chip boiler).

\subsection{Combination B: wood chip CHP and EB}

As seen in 3.1, the heat storage induces a higher cost efficiency in the operation of the CHP unit. However, the heat storage has little or no effect on the operation of the EB, due to the competitiveness of the oil boiler. This competitiveness is present even in the no-tax scenario, indicating that electricity prices and grid tariffs, particularly in Latvia and
Lithuania, are at such a level that EB operation is economically infeasible. Taxes and subsidies have an impact in Estonia due to its relatively lower electricity price, making the EB feasible to operate in a no-tax scenario (see Figs. 6 and 7).

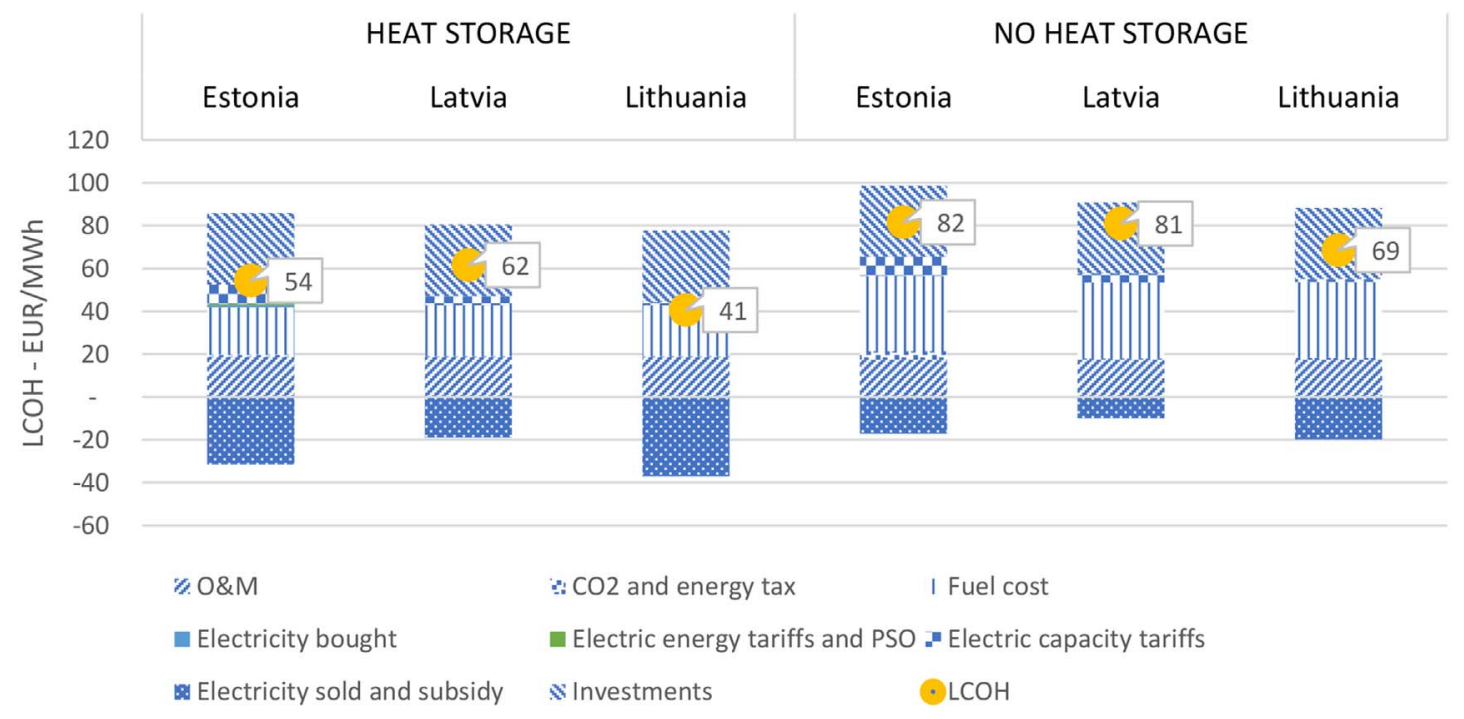

Fig. 6. Levelized cost of heat for Combination $\mathrm{B}(\mathrm{CHP}+\mathrm{EB})$ divided into main cost components. 


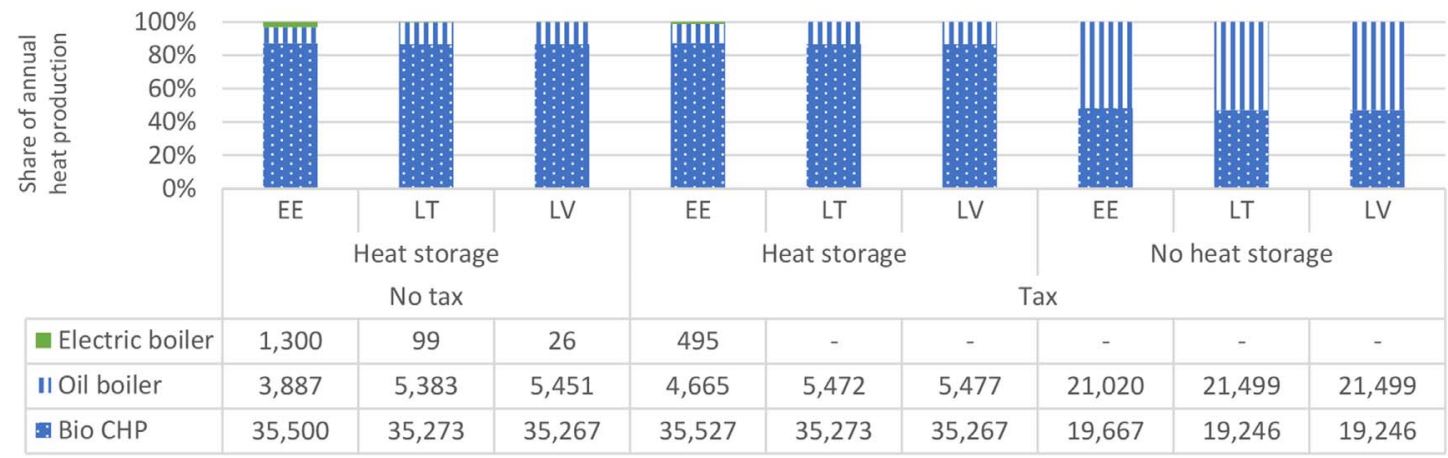

Fig. 7. Fuel distribution of Combination B (CHP + EB).

\subsection{Combination C: wood chip boiler}

The heat storage enables a nearly full utilization of the wood chip boiler, but the LCOHs for the different scenarios are the same regardless of storage. The increased O\&M costs induced by the increased operation of the wood chip boiler in the heat storage variations displace the higher costs of using oil in the no-storage scenarios. Changes in taxation have no impact on operation, indicating that biomass is competitive with oil regardless of taxes. Although the costs are roughly the same, heat storage offers small environmental and national economic benefits by facilitating a reduction in $\mathrm{CO}_{2}$, a reduction in imported fuels, and increased use of domestic fuels (see Figs. 8 and 9).

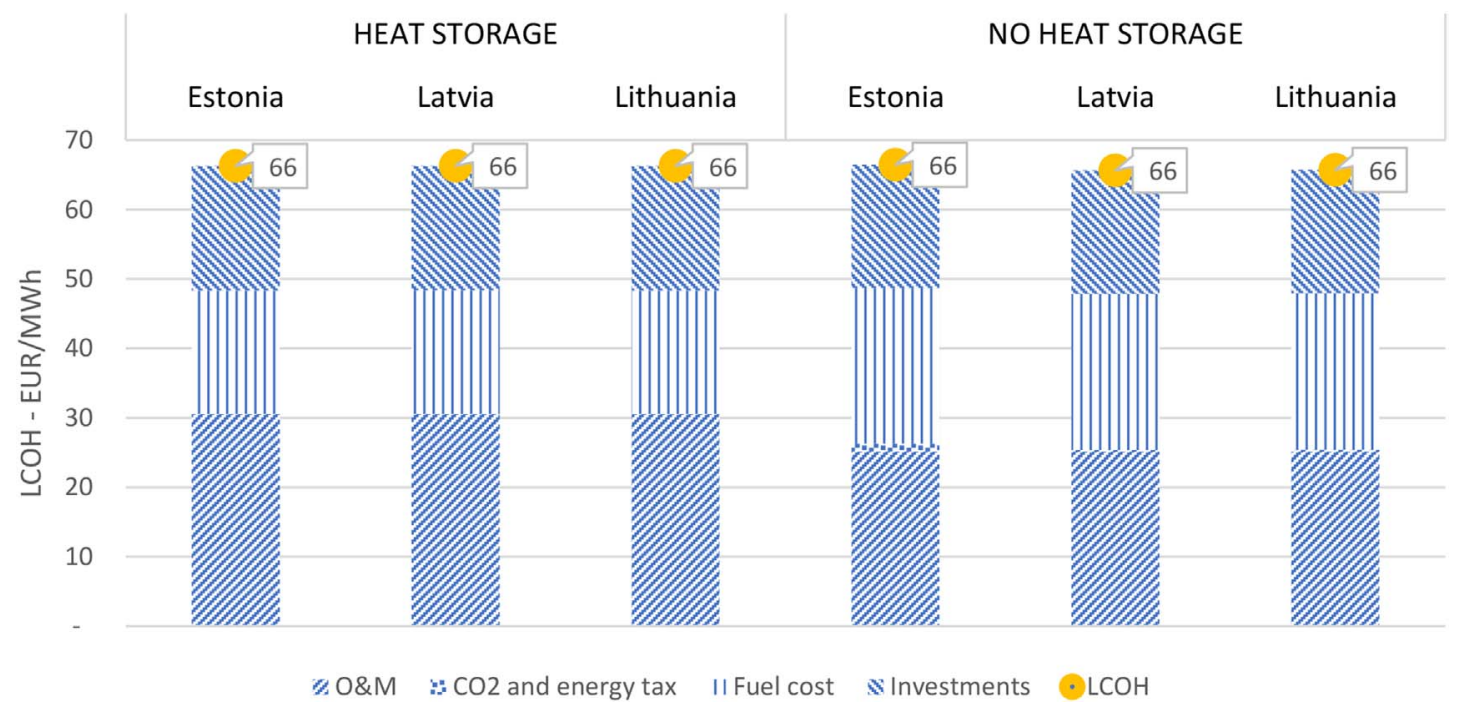

Fig. 8. Levelized cost of heat for Combination C (wood chip boiler) divided into main cost components.

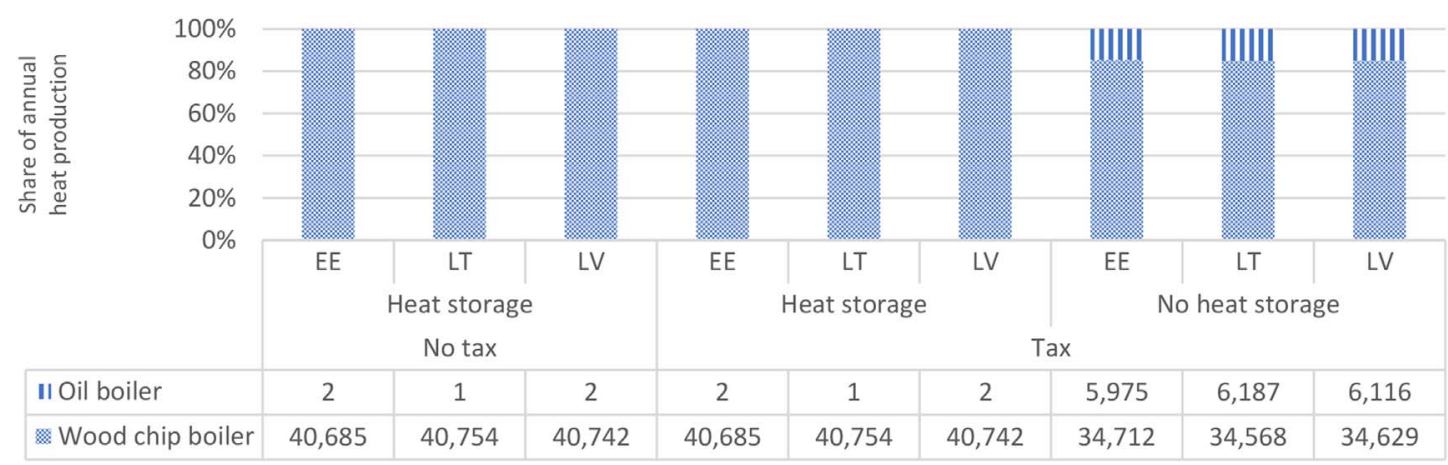

Fig. 9. Fuel distribution in Combination C (wood chip boiler). 


\subsection{Combination D: wood chip boiler $+E B$}

Unlike CHP, the wood chip boiler is allowed to produce at a partial load. Thus, the impact of storage is not as significant as in the previous scenarios. This is also reflected in the $\mathrm{LCOH}$, which is almost unchanged between the cases with and without storage. As in the scenario reported in section 3.2, an absence of taxes leads to increased production on EBs in Estonia (see Figs. 10 and 11). and heat storage yields the lowest LCOH. By a small margin, Lithuania deviates towards CHP with an EB. It can be argued that since the investment costs are significantly higher for the combination of CHP and EB (19.9 MEUR vs. 3.8 MEUR), and since this combination is solely dependent on electricity prices, the small margin to the wood chip boiler and EB combination might incentivize an investor to prefer this solution. In this case, the inflexible supply/flexible demand solution appears attractive, which might contrast with the Baltic priorities for

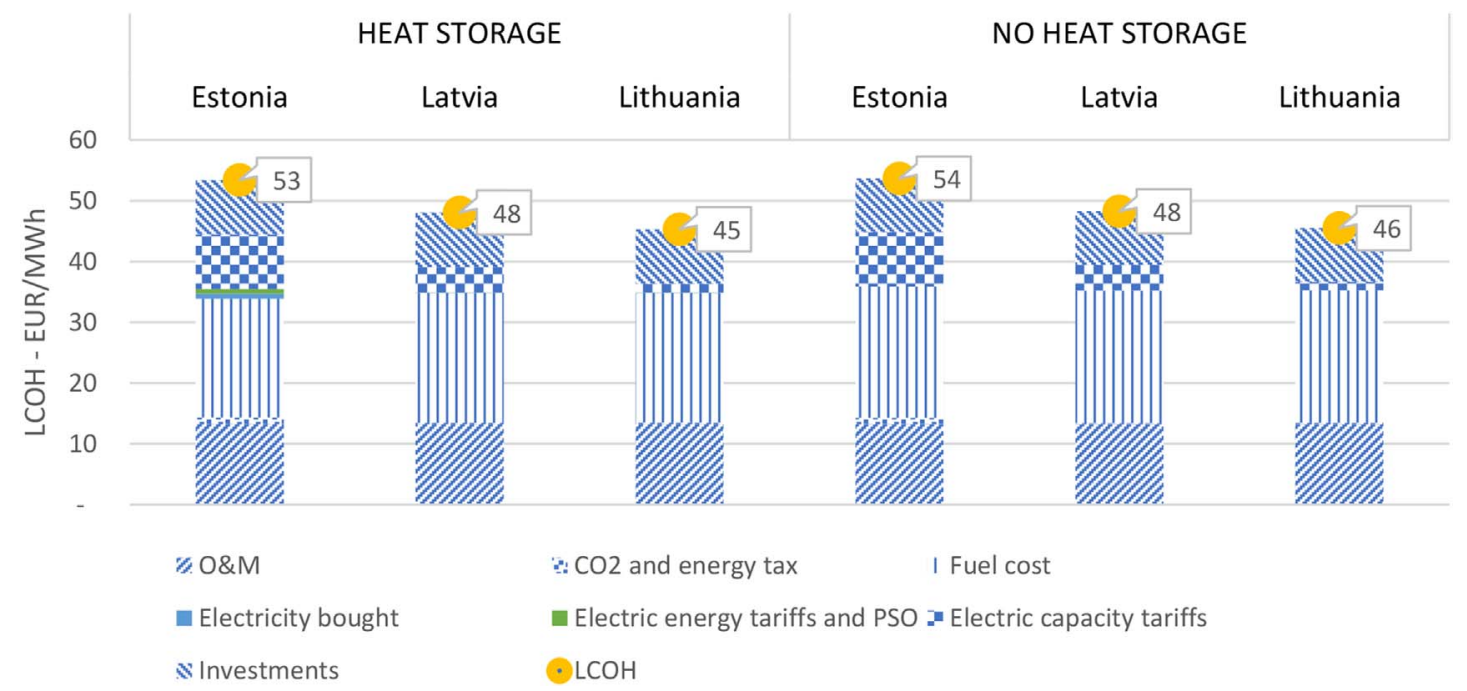

Fig. 10. Levelized cost of heat for Combination D (wood chip boiler $+\mathrm{EB}$ ) divided into main cost components.

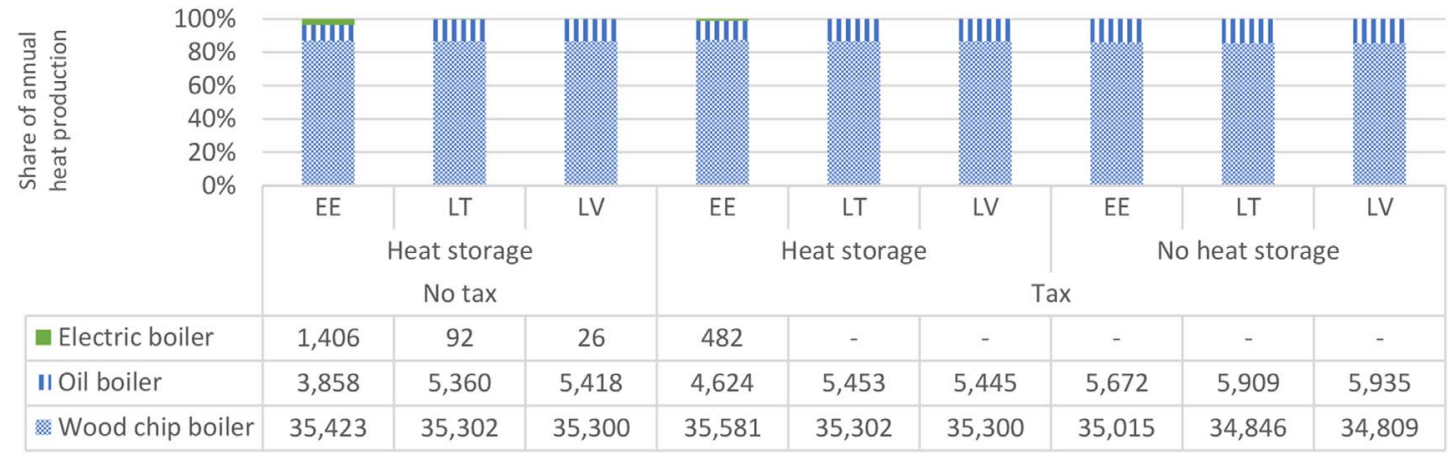

Fig. 11. Fuel distribution in Combination D (biomass boiler + EB).

\subsection{Discussion of results}

Table 8 indicates incentives to invest in flexible technologies, represented by LCOH. Here, the LCOHs of the scenarios with and without heat storage show that the combination of the wood chip boiler, the EB,

Table 8

Levelised costs of heat for all scenarios with tax. The color scale is read vertically and indicates the $\mathrm{LCOH}$ for each country, where green is low and red is high.

\begin{tabular}{|llccc|}
\hline Technological combination & Heat storage & EE & LV & LT \\
\hline A - CHP + wood chip boiler & Storage & -62 & -75 & -67 \\
A - CHP + wood chip boiler & No storage & -78 & -85 & -80 \\
\hline B - CHP + EB & Storage & -54 & -62 & -41 \\
B - CHP + EB & No storage & -82 & -81 & -69 \\
\hline C - large wood chip boiler & Storage & -66 & -66 & -66 \\
C - large wood chip boiler & No storage & -66 & -66 & -66 \\
\hline D - wood chip boiler + EB & Storage & -53 & -48 & -45 \\
D - wood chip boiler + EB & No storage & -54 & -48 & -46 \\
\hline
\end{tabular}

CHP-based DH. The large differences in economy and operation between scenarios with and without storage indicate that, internally, plants can utilize their technologies flexibly in the presence of heat storage. This internal flexibility supports a better utilization of leastcost production technologies, which is reflected in the lower LCOH of these scenarios.

The power charge components in the grid tariffs paid for utilizing the EB have disproportionally high costs compared to the amount of heat produced by the EB. For example, in the case of Estonia, this cost is $600 \mathrm{EUR} / \mathrm{MWh}$ heat, in addition to variable costs. This issue is not new in the context of DH. An earlier study showed how such charges could result in higher payments for longer durations, even when utility services are used only for a limited period of time (Athawale and Felder, 2014). A normal capacity tariff is similar to an investment cost, meaning that the more it is used, the smaller the cost per unit. Whereas removing capacity grid tariffs reduces the $\mathrm{LCOH}$, it does not shift the relative $\mathrm{LCOH}$ sufficiently to incentivize a different technology choice, as seen in Table 9. 
Table 9

Levelised costs of heat for all scenarios with tax and without capacity grid tariffs.

\begin{tabular}{|llccc|}
\hline Technological combination & Heat storage & EE & LV & LT \\
\hline A - CHP + wood chip boiler & Storage & -62 & -75 & -67 \\
A - CHP + wood chip boiler & No storage & -78 & -85 & -80 \\
\hline B - CHP + EB & Storage & -45 & -57 & -39 \\
B - CHP + EB & No storage & -73 & -77 & -67 \\
\hline C - large wood chip boiler & Storage & -66 & -66 & -66 \\
C - large wood chip boiler & No storage & -66 & -66 & -66 \\
\hline D - wood chip boiler + EB & Storage & -44 & -44 & -44 \\
D - wood chip boiler + EB & No storage & -45 & -44 & -44 \\
\hline
\end{tabular}

The results also illustrate the large share of heat production covered by the CHP. The CHP has a lower marginal heat production cost, resulting in the electricity production being close to baseload (ranging from 6527 to 6569 full-load hours in 2016) in all CHP scenarios with storage and only slightly less without taxes and subsidies. In this technology setup, the subsidies Estonia and Lithuania provide for CHP have a negligible impact on operations, though they do serve as significant investment incentives. Whereas the operational impact of subsidies and taxes is small, the CHP subsidies dampen market-based signals for flexibility because they provide out-of-market incentives for operation. Blumberga et al. (2014) shows that a similar phenomenon occurs in Latvia (see Fig. 11).

Regarding the EB, the limited or non-existent operation (75 full-load hours in Combination B with tax in Estonia and less or none in Latvia and Lithuania and in other scenarios) illustrates the absent need for EB operation under current conditions. EB operation improves to varying degrees in the absence of taxes in all countries. An excerpt from the operation in scenario A1 (CHP + EB with tax and storage) in Estonia shows that the EB can operate flexibly, as seen in Fig. 12. Low DSO and TSO electricity tariffs during the night, combined with low electricity spot prices, allow the EB to operate across two periods. This result corresponds to the findings of Kirkerud et al. (2016). Fig. 12 shows the baseload-like operation of the CHP plant.

Though this operational pattern of CHP and EB is the best solution in private economic terms, it contradicts the initial assumption for the system scale, that is, an increased need for flexible production and consumption to integrate VRE. The Baltic and Nordic power systems already handle significant shares of VRE, and these shares are expected to increase in Europe according to 2030 targets (European Commission, 2014). In combinations A and B (with storage and CHP), CHP runs as a baseload that is almost unchanged until 2035, even in variations without taxes and subsidies. Without storage, CHP operation is limited and displaced by other technologies. This, together with the low EB operation, indicates that the electricity market requires flexibility, not in the form of electricity consumption or reduced CHP production, but, rather, in the form of increased CHP production under the given conditions.

\subsection{Sensitivity to $O \& M$ and investment costs}

The similarity of the LCOH for combinations B (CHP + EB) and D (wood chip boiler $+\mathrm{EB}$ ) brings into question whether the results would be significantly different in the event of small changes in costs. The investment cost of CHP is explored because investment is a more significant share (24-29\%) of the LCOH in the CHP scenarios with storage than it is in the wood chip boiler scenarios (9-14\%). Likewise, O\&M costs are significant in the scenarios with the wood chip boiler. O\&M is sub-divided into variable (EUR/MWh) as well as fixed (EUR/year) costs, where the fixed part is analyzed here. Fig. 13 displays the results of the sensitivity analyses, in which the two combinations (B and D with storage) are compared, such that the values represented by each line describe the differences between the combinations. This illustrates whether each combination is robust against its closest alternative. The figure shows that the Estonian combinations are sensitive to changes in both categories, while Lithuania experiences only a minor shift in response to an increased CHP investment cost.

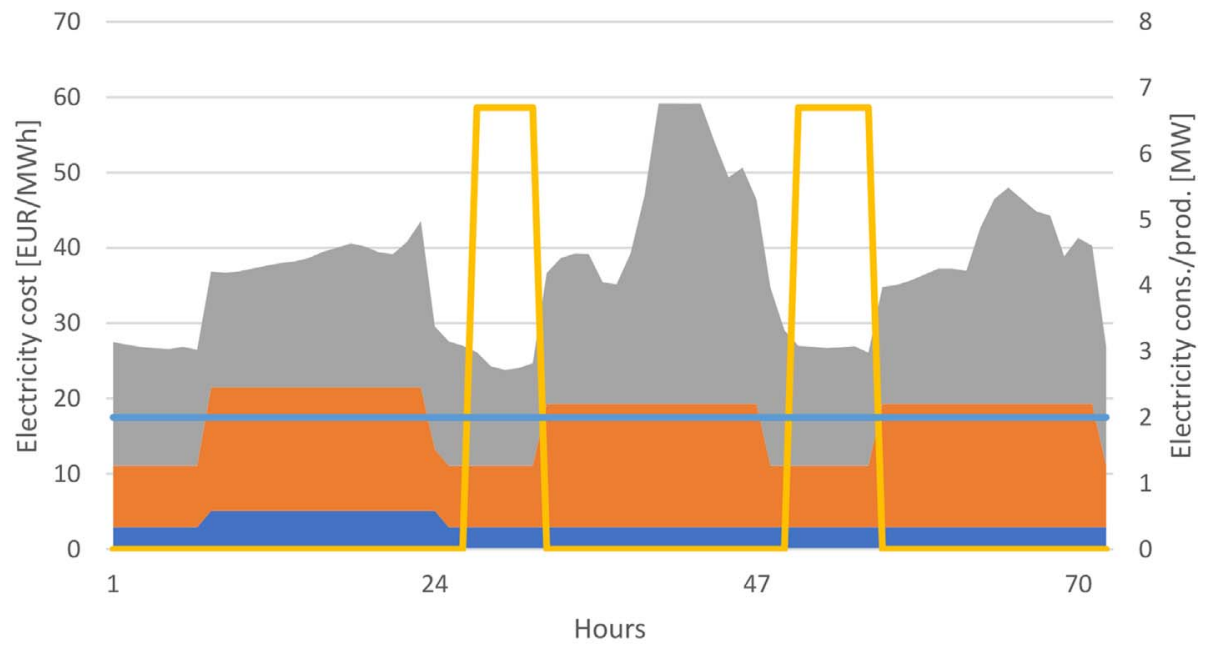

DSO tariff $\square$ TSO tariff $\amalg$ Electricity spot price $\longrightarrow$ Electric boiler $\longrightarrow$ Wood chip CHP

Fig. 12. Optimized operation for the first three days of January 2016 in Estonia. 


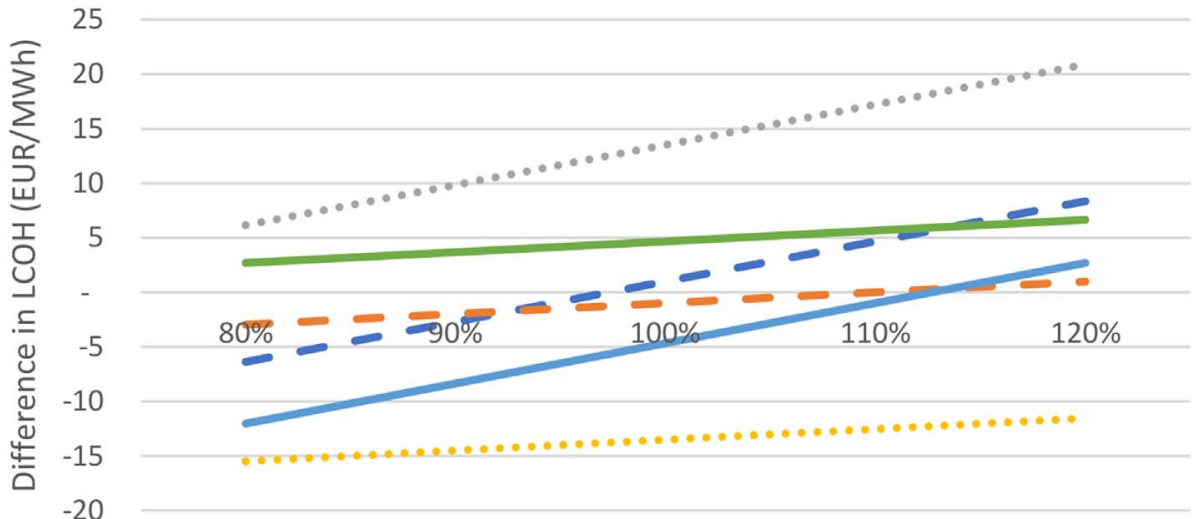

$-20$
Fig. 13. Sensitivity analyses for the fixed O\&M costs for the wood chip boiler and the investment costs for the CHP. Vertical scale depicts the difference of alternatives from the base case (at 100\%). For example, the solid green line depicts the difference between Combination $\mathrm{D}$ and the base value of Combination B. Negative values indicate a lower $\mathrm{LCOH}$ than the other scenario. (For interpretation of the references to color in this figure legend, the reader is referred to the Web version of this article.)

\section{Conclusion}

By analyzing scenarios based on technological combinations and policy conditions, this study explored how current policies on taxes and subsidies affect incentives for investment in flexible technologies, focusing on the coupling of the DH and electricity systems the Baltic countries. Additionally, impacts of electricity T\&D tariffs and heat storages were explored.

Investment incentives were evaluated using the proxy of the $\mathrm{LCOH}$, integrating investment and O\&M costs over the economic life of the DH plant. Operations were analyzed in terms of the share of heat production from flexible and non-flexible technologies.

On investment can be concluded.

- Current policies in Estonia, Latvia, and Lithuania are not directed at increased flexibility from the coupling of DH and electricity systems. While investment incentives are offered for CHP, direct flexibility incentives beyond electricity market signals are absent for CHP and $\mathrm{P} 2 \mathrm{H}$.

- Current policies incentivize investment in technology combinations with inflexible production and flexible consumption. The combination of the wood chip boiler, the EB, and heat storage has the lowest $\mathrm{LCOH}$ and, thus, the highest investment incentive in Estonia and Latvia. In Lithuania, the CHP-EB combination has a marginally better $\mathrm{LCOH}$. Despite this lower cost, the preferred technology combination in Lithuania is likely to be the second-most attractive alternative (the wood chip boiler and the EB) due to CHP being capital-intensive and sensitive to power prices.

- Heat storage is a no-regrets technology in that heat storage generally improves LCOH for all technological setups and enables plants to respond flexibly to external signals, such as electricity spot market prices.

- Charges under tariffs based on the maximum yearly capacity drawn from the grid are not prohibitive to the use of EBs, but represent a considerable additional cost, particularly when compared to the very low or absent cost of EB production.

On operation can be concluded.

- Current taxes and subsidies only marginally impact the operation of EB and CHP. Instead, energy prices and electricity T\&D tariffs impact operation of these technologies.

- Operation of EB is marginal compared to the CHP and wood chip boiler. The relatively low biomass prices encourage near-baseload generation on CHP and wood chip boiler, while the electricity price combined with electricity T\&D tariffs make EB operation uncompetitive. Under these conditions, the importance of $\mathrm{EB}$ as a flexible DH technology is likely to be for shorter peaks, and possibly on the ancillary services markets instead of the electricity spot market.

\subsection{Future work}

The extant research has not yet divided O\&M costs into labor and other components. However, O\&M is a significant reason for the electric- and wood chip boiler combination being the least costly. Thus, an increased focus on O\&M is necessary to determine whether this factor could prompt a shift toward other technologies.

Though the impact of taxes on operations has been analyzed, the specific impact of electricity tariffs has not yet been examined. Future studies could reveal whether changes to tariffs impact the operation of electric boilers.

The Latvian exemption of EB from the electricity tax ended January 1, 2017. Further analyses could examine the changes brought by this shift in policy.

Estonia's electricity tariffs changed significantly in July 2017 and might lead to different results.

While the present study prioritized the running of a large array of scenarios, we did not conduct sensitivity analyses on electricity and wood chip prices.

The plant-scale analysis pursued by the present study provides insight into local consequences. This perspective could be broadened in scale by using a system model. Extending the analysis in this manner would provide additional insight into the roles and benefits of both flexible and inflexible technologies in the energy system.

\section{Acknowledgements}

This paper was prepared as part of the Flex4RES (www.flex4RES. org) research project, which is supported by Nordic Energy Research. Furthermore, EMD International A/S provided a software license for the academic use of energyPRO. The authors are grateful to both organizations for their support for the study. Neither organization was in any other way involved in or responsible for the study. Additionally, we wish to extend our gratitude to the reviewers of this article, whose feedback has provided input for valuable discussions among the authors and relevant revisions of the study. 


\section{Appendix A. Supplementary data}

Supplementary data related to this article can be found at http://dx. doi.org/10.1016/j.jup.2018.02.001.

\section{References}

ABB, 2012. Latvia Energy Efficiency Report.

Athawale, R., Felder, F.A., 2014. Incentives for combined heat and power plants: how to increase societal benefits? Util. Pol. 31, 121-132. http://dx.doi.org/10.1016/j.jup. 2014.10.005.

Baltpool, 2017. Supply price | Energy Exchange | BALTPOOL [WWW Document]. Biomass Exch. - Supply Price. URL. http://www.baltpool.eu/en/supply-price/?mwh, Accessed date: 6 June 2017.

Bazbauers, G., Cimdina, G., 2011. The role of the Latvian district heating system in the development of sustainable energy supply. Sci. J. Riga Tech. Univ. Environ. Clim. Technol. 7. http://dx.doi.org/10.2478/v10145-011-0024-0.

Bergaentzle, C., Skytte, K., Soysal, E.R., Boscan, L., Olsen, O.J., 2017. Regulatory barriers for activating flexibility in the Nordic-Baltic electricity market. Int. Conf. Eur. Energy Mark. EEM. http://dx.doi.org/10.1109/EEM.2017.7981948.

Blarke, M.B., 2012. Towards an intermittency-friendly energy system: comparing electric boilers and heat pumps in distributed cogeneration. Appl. Energy 91, 349-365. http://dx.doi.org/10.1016/j.apenergy.2011.09.038.

Blumberga, D., Barisa, A., Veidenbergs, I., Blumberga, A., Kuhi-Thalfeldt, R., 2014 Evaluation of RES-e support policies in the baltic states. In: The 9th International Conference "Environmental Engineering 2014." Vilnius Gediminas Technical University Press “Technika" 2014, Vilnius, Lithuania, http://dx.doi.org/10.3846/ enviro.2014.255.

Colmenar-Santos, A., Rosales-Asensio, E., Borge-Diez, D., Blanes-Peir, J.J., 2016. District heating and cogeneration in the EU-28: current situation, potential and proposed energy strategy for its generalisation. Renew. Sustain. Energy Rev. 62, 621-639. http://dx.doi.org/10.1016/j.rser.2016.05.004.

Connolly, D., Lund, H., Mathiesen, B.V., Leahy, M., 2010. A review of computer tools for analysing the integration of renewable energy into various energy systems. Appl. Energy 87, 1059-1082. http://dx.doi.org/10.1016/j.apenergy.2009.09.026.

Danish Energy Agency, 2015. Technology Data for Energy Plants. Copenhagen.

Danish Energy Agency, 2016a. Regneark Med Tabeller - Samfundsøkonomiske Beregningsforudsætninger.

Danish Energy Agency, 2016b. Technology Data for Energy Plants. Copenhagen.

EMD International A/S, 2016. User's Guide EnergyPRO.

EMD International A/S, 2017. Production on Hvide Sande District Heating Plant [WWW Document]. Web Page. URL. http://www.emd.dk/desire/hvidesande/, Accessed date: 30 March 2017.

EMD International A/S, 2018. energyPRO.

Euroheat, Power, 2015. District Heating and Cooling - Country by Country 2015 Survey. Euroheat \& Power, Brussels.

European Commission, 2014. A Policy Framework for Climate and Energy in the Period from 2020 to 2030. EUR-lex - 52014DC0015-EN.

European Commission, 2017. Weekly Oil Bulletin - European Commission [WWW Document]. Wkly. Oil Bull URL. https://ec.europa.eu/energy/en/data-analysis/ weekly-oil-bulletin, Accessed date: 6 June 2017.

Eurostat, 2017. Eurostat - Data Explorer [WWW Document]. EU Trade since 1988 by HS2,4,6 CN8. URL. http://appsso.eurostat.ec.europa.eu/nui/ submitViewTableAction.do, Accessed date: 9 October 2017

Gaigalis, V., Skema, R., Marcinauskas, K., Korsakiene, I., 2016. A review on heat pumps implementation in Lithuania in compliance with the national energy strategy and EU policy. Renew. Sustain. Energy Rev. 53, 841-858. http://dx.doi.org/10.1016/j.rser. 2015.09.029.

Hvelplund, F., Lund, H., 1998. Feasibility Studies and Public Regulation in a Market Economy, ISP Skriftserie nr. 218. Institute for Development and Planning. Aalborg University, Aalborg.

IEA, 2014a. Lithuania: Electricity and Heat [WWW Document]. Stat. Search URL. https://www.iea.org/statistics/statisticssearch/report/?country = Lithuania\& product=electricityandheat, Accessed date: 6 July 2017 .

IEA, 2014b. The Power of Transformation. IEA, Paris. http://dx.doi.org/10.1007/ BF01532548.

IEA, 2016. Nordic energy technology perspectives 2016-nordic energy research [WWW document]. Nord. Energy Technol. Perspect 2016 URL. http://www.nordicenergy. org/project/nordic-energy-technology-perspectives/, Accessed date: 10 January 2017.

IEA, 2017. IEA - Statistics Search [WWW Document]. IEA Stat. Search URL. https:// www.iea.org/statistics/statisticssearch/, Accessed date: 10 August 2017.

Kirkerud, J.G., Trømborg, E., Bolkesjø, T.F., 2016. Impacts of electricity grid tariffs on flexible use of electricity to heat generation. Energy 1-9. http://dx.doi.org/10.1016/ j.energy.2016.06.147.

Klavs, G., Kudrenickis, I., 2016. Energy Efficiency Trends and Policies in LATVIA. Riga.

Konstantinaviciute, I., Bobinaite, V., Tarvydas, D., Gatautis, R., 2013. Renewable energy in the Lithuanian heating sector. Energy Pol. 59, 32-43. http://dx.doi.org/10.1016/j. enpol.2013.04.016.

Kuhi-Thalfeldt, R., Valtin, J., 2009. Combined heat and power plants balancing wind power. Oil Shale 26, 294. http://dx.doi.org/10.3176/oil.2009.3S.11.

Kveselis, V., Dzenajavičienė, E.F., Masaitis, S., 2017. Analysis of energy development sustainability: the example of the Lithuanian district heating sector. Energy Pol. 100, 227-236. http://dx.doi.org/10.1016/j.enpol.2016.10.019.
Lannoye, E., Flynn, D., O'Malley, M., 2015. Transmission, variable generation, and power system flexibility. IEEE Trans. Power Syst. 30, 57-66. http://dx.doi.org/10.1109/ TPWRS.2014.2321793.

Lauka, D., Gusca, J., Blumberga, D., 2015. Heat pumps integration trends in district heating networks of the Baltic States. Procedia Comput. Sci. 52, 835-842. http://dx. doi.org/10.1016/j.procs.2015.05.140.

Likumi, 2016. Guidelines of Energy Development for 2016-2020 [WWW Document]. URL. https://m.likumi.lv/doc.php?id=280236, Accessed date: 6 August 2017.

Likumi, 2017. Noteikumi Par Elektroenerǵijas Ražošanu Un Cenu noteikšanu, Ražojot Elektroenerǵiju Koğenerācijā [WWW Document]. URL. https://m.likumi.lv/doc. php?id=189260, Accessed date: 6 July 2017.

Lund, H., 2003. Technical Design of Flexible Sustainable Energy Systems, in: 2nd Dubrovnik Conference on Sustanaible Development Og Energy, Water and Environment Systems. Balkema Publishers, A.A, Taylor \& Francis The Netherlands,, Dubrovnik, pp. 1-10.

Lund, H., Andersen, a. N., 2005. Optimal designs of small CHP plants in a market with fluctuating electricity prices. Energy Convers. Manag. 46, 893-904. http://dx.doi. org/10.1016/j.enconman.2004.06.007.

Lund, H., Hvelplund, F., Kass, I., Dukalskis, E., Blumberga, D., 1999. District heating and market economy in Latvia. Energy 24, 549-559. http://dx.doi.org/10.1016/S03605442(99)00017-1.

Lund, H., Šiupšinskas, G., Martinaitis, V., 2005. Implementation strategy for small CHPplants in a competitive market: the case of Lithuania. Appl. Energy 82, 214-227. http://dx.doi.org/10.1016/j.apenergy.2004.10.013.

Lund, P.D., Lindgren, J., Mikkola, J., Salpakari, J., 2015. Review of energy system flexibility measures to enable high levels of variable renewable electricity. Renew. Sustain. Energy Rev. 45, 785-807. http://dx.doi.org/10.1016/j.rser.2015.01.057.

Macevičius, V., 2015. Lithuanian district Heating Sector: Present Situation and Future of the Lithuanian Energy Market.

Mathiesen, B.V., Lund, H., Connolly, D., Wenzel, H., Ostergaard, P.A., Möller, B., Nielsen, S., Ridjan, I., KarnOe, P., Sperling, K., Hvelplund, F.K., 2015. Smart Energy Systems for coherent $100 \%$ renewable energy and transport solutions. Appl. Energy 145, 139-154. http://dx.doi.org/10.1016/j.apenergy.2015.01.075.

Miskinis, V., Slihta, G., Rudi, Y., 2006. Bio-energy in the baltic states: current policy and future development. Energy Pol. 34, 3953-3964. http://dx.doi.org/10.1016/j.enpol. 2005.09.021.

National Commission for Energy Control and Prices, 2016. Tariffs for Electricity from RES 2015 year [WWW Document]. URL. http://www.regula.lt/en/Pages/tariffs-for electricity-from-res-2015-year.aspx, Accessed date: 7 June 2017.

Norsk Energi and Thema Consulting Group, 2014. Fjernvarmens Rolle I Energisystemet. Oslo.

Olsen, O.J., Munksgaard, J., 1998. Cogeneration and taxation in a liberalized Nordic power market. Util. Pol. 7, 23-33. http://dx.doi.org/10.1016/S0957-1787(98)00002-2.

Østergaard, P.A., Andersen, A.N., 2015. Booster heat pumps and central heat pumps in district heating. Appl. Energy. http://dx.doi.org/10.1016/j.apenergy.2016.02.144.

Perednis, E., Katinas, V., Markevičius, A., 2012. Assessment of wood fuel use for energy generation in Lithuania. Renew. Sustain. Energy Rev. 16, 5391-5398. http://dx.doi. org $/ 10.1016 /$ j.rser.2012.05.044.

Roos, I., Soosaar, S., Volkova, A., Streimikene, D., 2012. Greenhouse gas emission reduction perspectives in the Baltic States in frames of EU energy and climate policy. Renew. Sustain. Energy Rev. 16, 2133-2146. http://dx.doi.org/10.1016/j.rser.2012. 01.013.

Salpakari, J., Mikkola, J., Lund, P.D., 2016. Improved flexibility with large-scale variable renewable power in cities through optimal demand side management and power-toheat conversion. Energy Convers. Manag. 126, 649-661. http://dx.doi.org/10.1016/ j.enconman.2016.08.041.

Sekmokas, A., 2012. The National Energy Independence Strategy Presented to the Seimas [WWW Document]. Press Releases. URL. http://www.lrs.lt/sip/portal.show?p_r = 9252\&p_k $=2 \& p_{\_} t=124673$, Accessed date: 6 August 2017.

Skytte, K., Olsen, O.J., Rosenlund Soysal, E., Møller Sneum, D., 2017. Barriers for district heating as a source of flexibility for the electricity system. J. Energy Mark 10, 1-19. http://dx.doi.org/10.21314/JEM.2017.161.

Sneum, D.M., Sandberg, E., Soysal, E.R., Skytte, K., Olsen, O.J., 2016. Framework Conditions for Flexibility in the District Heating-electricity Interface, Flex4RES Project. Lyngby.

Soysal, E.R., Møller Sneum, D., Skytte, K., Olsen, O.J., Sandberg, E., 2016. Electric boilers in district heating systems: A comparative study of the Scandinavian market conditions - DTU orbit. In: Swedish Association for Energy Economics (Ed.), Swedish Association for Energy Economics Conference 2016. Swedish Association for Energy Economics, Luleå.

Streckiene, G., Martinaitis, V., Andersen, A.N., Katz, J., 2009. Feasibility of CHP-plants with thermal stores in the German spot market. Appl. Energy 86, 2308-2316. http:// dx.doi.org/10.1016/j.apenergy.2009.03.023.

Riigi Teataja, 2014. Electricity Market Act [WWW Document]. URL. https://www. riigiteataja.ee/en/eli/528082014005/consolide, Accessed date: 6 July 2017.

The Norwegian Water Resources and Energy Directorate, 2015. Kostnader i energisektoren. Oslo.

The World Bank, 2017. World Development Indicators | Data [WWW Document]. World Dev. Indic Dataset. URL. http://data.worldbank.org/data-catalog/worlddevelopment-indicators, Accessed date: 6 July 2017.

Trømborg, E., Havskjold, M., Bolkesjø, T.F., Kirkerud, J.G., Tveten, Å.G., 2017. Flexible use of electricity in heat-only district heating plants. Int. J. Sustain. Energy Plan. Manag 12, 29-46. http://dx.doi.org/10.5278/ijsepm.2017.12.4.

Ziemele, J., Pakere, I., Blumberga, D., 2016. The future competitiveness of the nonEmissions Trading Scheme district heating systems in the Baltic States. Appl. Energy 162, 1579-1585. http://dx.doi.org/10.1016/j.apenergy.2015.05.043. 